rectal swab culture method in detection of gastrointestinal colonization with vancomycin-resistant enterococci. Clin Infect Dis 2002;34:167-172.

7. Morris JG Jr, Shay DK, Gebden JN, et al. Enterococci resistant to multiple antimicrobial agents, including vancomycin: establishment of endemicity in a university medical center. Ann Intern Med 1995; 123:250-259.

8. Siddiqui $\mathrm{AH}$, Harris $\mathrm{AD}$, Hebden J, Wilson PD, Morris JG Jr, Roghmann M-C. The effect of active surveillance for vancomycin-resistant enterococci in high-risk units on vancomycinresistant enterococci incidence hospital-wide Am I Infect Control 2002;30:40-43.

9. Edmond MB, Ober JF, Dawson JD, Weinbaum DL, Wenzel RP. Vancomycinresistant enterococcal bacteremia: natura history and attributable mortality. Clin Infect Dis 1996;23:1234-1239.

10. Chang S, Sievert DM, Hageman JC, et al. Infection with vancomycin-resistant Staphylococcus aureus containing the vanA resistance gene. N Engl J Med 2003;348:1342-1347.

C. Glen Mayhall, MD

University of Texas Medical Branch Galveston, Texas

\section{Nosocomial Outbreak of Serratia marcescens in a Neonatal Intensive Care Unit}

\section{To the Editor:}

In the August 2002 issue of Infection Control and Hospital Epidemiology, Assadian et al. reported a nosocomial outbreak of Serratia marcescens in their neonatal unit. ${ }^{1} \mathrm{We}$ believe that this study placed an excessive emphasis on the environment and on Serratia itself, a bacteria belonging to the tribe Klebsielleae, which also includes Klebsiella and Enterobacter organisms. Although tribe Klebsielleae bacteria grow in almost anything wet, they do not spread from the environment to individuals nor do they possess the pathogenic mechanisms necessary to enter sterile enclosures of the body. They rarely cause community infections despite their presence in vegetables and almost anywhere we go. Since Maki and Martin reported that tribe Klebsielleae bacteria grow well in parenteral solutions at room temperature, ${ }^{2}$ several studies have shown that combining intravenous fluids on wards is risky compared with using commercially prepared standardized formulations. ${ }^{3-5}$ Tribe Klebsielleae bacteria rarely cause bacteremia outbreaks in adults because combining intravenous fluids for adults is uncommon.

Assadian et al. defined an index case and discussed potential mechanisms for dissemination of the organism in the unit. Despite the lack of evidence of the efficacy of disinfecting the environment, they considered that the outbreak was caused by "inadequate surface disinfection through incorrectly calculated disinfection solutions." But they did not mention the most important point: how did the bacteria reach the blood and brains of the patients in the first place? If we honor the epidemiology of these infections, we can conclude that they probably entered through parenteral fluids. The authors did not mention whether all of the infected patients had an infusion; we assume that they did. Suggesting that "future outbreak control measures should concentrate on the intensity of colonization of not only the infants" could lead readers to a frantic search for bacteria that remain innocent bystanders as long as we do not allow them access to the patient's bloodstream.

In conclusion, we believe that the study performed by Assadian et al. neglected much of the epidemiologic knowledge about tribe Klebsielleae bacteria septicemia outbreaks. Calculation of intravenous fluids and electrolytes for pediatric patients has, in some places, a pretension of exact science, which leads to the policy of "my patient, my mixture," magnifying the metabolic risks and ignoring the microbiological hazards. The authors stated that "Combined intravenous fluid solutions are prepared in a laminar airflow in a separate clean room" and that is all they considered necessary to say. But a hood would not mend some common lapses such as using a stock bottle left at room temperature to prepare solutions for different patients. These risks will persist if we do not understand that we cannot have a different infusion for every patient, designed under the whims of each physician with a pocket calculator.

\section{REFERENCES}

1. Assadian O, Berger A, Aspöck C, Mustafa S, Kohlhauser C, Hirschl AM. Nosocomial outbreak of Serratia marcescens in a neonatal intensive care unit. Infect Control Hosp Epidemiol 2002;23:457-461.

2. Maki DG, Martin WT. Nationwide epidemic of septicemia caused by contaminated infusion products: IV. Growth of microbial pathogens in fluids for intravenous infusion. Infect Dis 1975;131:267-272.

3. Macias-Hernandez AE, Hernandez-Ramos I, Munoz-Barrett JM, et al. Pediatric primary gram-negative nosocomial bacteremia: a possible relationship with infusate contamination. Infect Control Hosp Epidemiol 1996;17:276-280.

4. Macias AE, Muñoz JM, Bruckner DA, et al. Parenteral infusions bacterial contamination in a multi-institutional survey in Mexico: considerations for nosocomial mortality. Am J Infect Control 1999;27:285290.

5. Hernandez-Ramos I, Gaitán-Meza J, GaitánGaitán E, et al. Extrinsic contamination of intravenous infusates administered to hospitalized children in Mexico.J Pediatr Infect Dis 2000;19:888-890.

Juan M. Muñoz, MD, MSc Alejandro E. Macías, MD Guanajuato University School of Medicine at León

León, Guanajuato, Mexico

\section{The authors reply.}

We thank the editor for giving us the opportunity to respond to the letter of Drs. Muñoz and Macias. They note that the potential risk of intravenous fluids was neglected in our article and not given the emphasis it deserves, which is not surprising because they have published intensively on this subject. ${ }^{1-3}$ We agree with Drs. Muñoz and Macias on the potential hazards of inadequate preparation of intravenous fluids. These hazards are well known and in view of the risks arising from microbial contamination, the preparation of intravenous fluids demands meticulous aseptic techniques. Working in a clean room can support such requirements. They also point out that not only Serratia, but also Enterobacter and Klebsiella organisms have the ability to grow well in parenteral solutions at room temperature. In addition, Pseudomonas species and the predominance of coagulase-negative staphylococci, Staphylococcus aureus, Candida albicans, and enterococci in nosocomial bloodstream infections since the mid 1980s should be mentioned. ${ }^{4,5}$ However, the statement that tribe Klebsielleae bacteria rarely cause bacteremia outbreaks in adults because combining intravenous fluids for adults is uncommon needs some correction as a result of many published studies about hematology-oncology patients and intensive care patients. 6,7 